\title{
CURRENT STATUS OF THE PLAINS POCKET MOUSE (PEROGNATHUS FLAVESCENS) IN EASTERN NEBRASKA
}

\author{
Keith Geluso ${ }^{1,3}$ and Greg D. Wright ${ }^{1,2}$
}

\begin{abstract}
Distribution of the plains pocket mouse (Perognathus flavescens) overlaps tallgrass prairies in northeastern parts of the species' range in the central United States. Distribution and abundance of the plains pocket mouse appears negatively impacted by agricultural practices during the last century due to the scarcity of records throughout the region. In eastern Nebraska, few plains pocket mice have been captured and no published account exists in recent decades. We investigated the current status of $P$. f. perniger, the eastern subspecies in Nebraska, because of a paucity of information regarding this subspecies' natural history and suspected extirpation from the state. We captured 56 P. $f$. perniger in 13 counties in northeastern and east-central Nebraska in 2008, including 10 counties lacking prior records. We also obtained data on its presence in extreme eastern Nebraska (Douglas and Lancaster counties) via a literature review and query for specimens in museums. Some individuals without darker-colored guard hairs represented the eastern limits of the western subspecies $P$. f. flavescens associated with the easternmost extent of the Sandhill Region of the state or other isolated sandy habitats. Across eastern Nebraska, many sites with captures of plains pocket mice appear to represent strongholds associated with isolated areas of friable, sandy soils. To date, presence of the species has not been detected in southeastern parts of the state. Conservation of habitats with sandy soils, along with implementation or continuance of disturbance regimes (i.e., grazing), will benefit this species and a number of other sand-adapted species in eastern Nebraska.
\end{abstract}

RESUmen.-La distribución del ratón de bolsillo de las llanuras (Perognathus flavescens) coincide con la de las praderas de pastizales altos en partes del noreste de su rango en el centro de los Estados Unidos. Su distribución y abundancia parece estar afectada de forma negativa por las prácticas agrícolas realizadas durante el último siglo, debido a la escasez de registros en toda la región. En el este de Nebraska, pocos ratones de bolsillo de las llanuras han sido capturados y no existe ningún registro publicado en décadas recientes. Investigamos el estado actual de $P$. $f$. perniger, la subespecie del este de Nebraska, debido a la escasez de información sobre su historia natural y su supuesta extirpación del estado. Capturamos 56 P. f. perniger en 13 condados en el noreste y centro-este de Nebraska en 2008, incluidos 10 condados que carecían de registros anteriores. También obtuvimos datos sobre su presencia en el extremo este de Nebraska (en los condados de Douglas y Lancaster) a través de una revisión de literatura y de búsqueda de especímenes en museos. Algunos individuos sin pelambre áspero y oscuro representaron los límites orientales de la subespecie occidental P. f. flavescens asociados con el extremo más oriental de la región arenosa del estado (Sandhill Region) u otros hábitats arenosos aislados. En el este de Nebraska, muchos sitios con capturas del ratón de bolsillo de las llanuras parecen representar un refugio asociado con áreas aisladas de suelos friables y arenosos. A la fecha, no se ha detectado la presencia de la especie en las partes del sureste del estado. La conservación de los hábitats con suelos arenosos, además de la implementación o la continuación de los regímenes de perturbación (i.e., el pastoreo) beneficiará a esta especie y a un número de otras especies adaptadas a la arena en el este de Nebraska.

During the last century, native grasslands have been plowed to establish agricultural croplands throughout much of the Great Plains (Samson and Knopf 1994). Such actions have resulted in tallgrass prairies being considered one of the most impacted ecosystems in North America, with losses of tallgrass prairies in states ranging from $82 \%$ to $99 \%$ since 1830 (Samson and Knopf 1994, Benedict et al. 1996). In eastern Nebraska, for example, only $2 \%$ of tallgrass prairies remain (Samson and Knopf 1994). Widespread conversion of native prairies has negatively impacted the distribution and abundance of mammals in the Great Plains, such as Franklin's ground squirrels (Poliocitellus franklinii), black-tailed prairie-dogs (Cynomys ludovicianus), and white-tailed jackrabbits (Lepus townsendii; Benedict et al. 1996, Fleharty and Channell 1997).

In the United States, distribution of the plains pocket mouse (Perognathus flavescens) overlaps tallgrass prairies in northeastern parts of its distribution, including eastern North Dakota, eastern South Dakota, western and

${ }^{1}$ Department of Biology, University of Nebraska at Kearney, Kearney, NE 68849.

${ }^{2}$ Present address: The Crane Trust, 6611 W. Whooping Crane Drive, Wood River, NE 68883.

${ }^{3}$ E-mail: gelusok1@unk.edu 
southern Minnesota, most of Iowa, eastern Nebraska, and northern Missouri (Monk and Jones 1996, Schwartz and Schwartz 2001). Abundance and distribution of the plains pocket mouse $(P . f$. perniger $)$ in that region appears negatively impacted by a reduction in habitat, with only limited captures reported for this subspecies throughout the region. Only relict populations remain in small, isolated areas with sandy or loessial soils in Minnesota (Birney 1999). In Iowa, $P$. f. perniger has been captured at only a few sites across the state (Wilson et al. 1996, Otto and White 2011), and in Missouri, records are known from only 2 counties in northern parts of the state (Easterla 1967, Schwartz and Schwartz 2001). In South Dakota, only 8 localities are reported for the subspecies (Reed and Choate 1986). And in Nebraska, only 10 specimens are known from 4 sites, all of which are in northeastern parts of the state (Jones 1964).

In eastern Nebraska, the current status of P. f. perniger is not understood (Schneider et al. 2005), and this subspecies might be extirpated within much of its former range (Jones 1964, Benedict et al. 2000). Its distributional range was stated as contracting because not a single individual was documented in eastern parts of the state during the last decade, despite an effort of $>35,000$ trap-nights (Benedict et al. 2000). Moreover, the Nebraska Game and Parks Commission lists $P$. $f$. perniger as one of the most at-risk mammalian taxons in the state (Schneider et al. 2005). Our primary objective was to determine the current status of $P . f$. perniger in eastern Nebraska, but we also summarized information about the species from published literature, unpublished theses, museum specimens, and data obtained during our field efforts. Throughout its distribution, most studies report that the plains pocket mouse is confined to sandy soils (Jones et al. 1983, Williams et al. 1993, see Monk and Jones 1996), and some postulate its distribution is discontinuous throughout its range because of such an association (Reed and Choate 1986). We predicted that if $P$. $f$. perniger still exists in eastern Nebraska, it likely inhabits areas with sandy soils.

\section{Methods}

From 6 June to 2 August 2008, we conducted a survey for $P$. flavescens in eastern Nebraska (Appendixes 1,2). We deployed Sherman live traps (model type LFATDG, H.B. Sherman, Tallahassee, FL) to catch small mammals but occasionally set mousetraps (Museum Special, Woodstream Corporation, Lititz, PA). Traps were placed in grazed and ungrazed upland grasslands in roadside right-of-ways, on private lands, and in state wildlife management areas. Traps generally were placed every $10 \mathrm{~m}$ on linear transects, but we occasionally set them at closer intervals where only limited sandy habitats existed. Many traps were set for a single night, whereas others were left in place for 2-3 consecutive nights and checked daily.

For each small mammal captured in traps or by hand, we recorded species, sex, age (juvenile or adult), and reproductive condition (nonreproductive, pregnant, lactating, or scrotal). For P. flavescens, we also recorded venter color (white, ochraceous, or having a slightly ochraceous wash) and data on habitat $<2 \mathrm{~m}$ from the capture site by visual estimation (percentage cover of grasses, forbs, shrubs, and bare ground; abundant species of plants; height of vegetation; and soil type). Most individuals were released at capture sites, but some mice were kept as voucher specimens. Vouchers and associated field notes were deposited in natural history collections in the Division of Zoology, University of Nebraska State Museum (UNSM), Lincoln, Nebraska. Coordinates of localities were determined with handheld global positioning units using North American Datum 1983.

We attempted to capture $P$. f. perniger near the 4 previously published localities of occurrence in Cuming, Knox, and Stanton counties reported by Jones (1964). We also located other potential trapping sites by using the DeLorme Nebraska Atlas and Gazetteer (DeLorme Mapping Company 2000) to locate large areas of land without roads described as "rangeland." Next, we searched surrounding areas for sandy soils and sparse ground cover. Areas depicted by light shading in the gazetteer generally corresponded with unbroken soils used for grazing domestic livestock. In northeastern and eastcentral Nebraska, many such areas consisted of sandy soils, but in southeastern Nebraska, most sites consisted of compact, silty soils.

To examine variation in coloration among specimens of plains pocket mice to assist with subspecific determination, we visited a number of museums that housed many specimens of both subspecies (P. f. flavescens and P. $f$. perniger). We visited collections at the UNSM; 
University of Nebraska at Kearney, Kearney, Nebraska; University of Kansas (KU), Lawrence, Kansas; Museum of Southwestern Biology (MSB), University of New Mexico, Albuquerque, New Mexico; and Sternberg Museum (FHSM), Fort Hays State University, Hays, Kansas.

\section{RESUlTs}

In eastern Nebraska, we trapped in 35 counties for plains pocket mice and accrued 8641 trap-nights. We captured 896 small mammals representing 15 species, including 394 North American deermice (Peromyscus maniculatus), 90 prairie voles (Microtus ochrogaster), 75 hispid pocket mice (Chaetodipus hispidus), 70 plains pocket mice ( $P$. flavescens), 64 white-footed deermice (Peromyscus leucopus), 62 Ord's kangaroo rats (Dipodomys ordii), 60 western harvest mice (Reithrodontomys megalotis), 29 meadow voles (Microtus pennsylvanicus), 24 thirteenlined ground squirrels (Ictidomys tridecemlineatus), 10 northern grasshopper mice (Onychomys leucogaster), 7 house mice (Mus musculus), 4 northern short-tailed shrews (Blarina brevicauda), 4 meadow jumping mice (Zapus hudsonius), 2 Elliot's short-tailed shrews (Blarina hylophaga), and 1 plains harvest mouse (Reithrodontomys montanus). Small mammals commonly associated with $P$. flavescens at sites included $D$. ordii and P. maniculatus, but all mammalian species listed above were captured in traplines with $P$. flavescens, except $B$. hylophaga, M. pennsylvanicus, and R. montanus.

\section{Distribution}

In eastern Nebraska, we captured $P$. flavescens at 28 localities in $57 \%$ (20 of 35) of counties with trapping effort (Fig. 1, Appendix 1). Based on the subspecific boundary depicted by Jones (1964), Hall (1981), and our examination of dorsal colorations, we captured 56 P. $f$. perniger in 13 counties, including northern Antelope, Boyd, Butler, Cuming, northern Holt, Knox, Madison, Merrick, Nance, Pierce, Platte, Polk, and Stanton (Fig. 1). We obtained records of individuals $<15 \mathrm{~km}$ from all 4 prior published localities in Cuming, Knox, and Stanton counties; the remaining 10 counties represent new county records for the subspecies. In contrast, we did not detect $P$. $f$. perniger in southeastern parts of the state (Fig. 1). Along the eastern distributional limits for $P$. $f$. flavescens in Nebraska, we captured 14 individuals in 9 counties (Fig. 1, Appendix 1), including 6 counties without prior records (Boone, Franklin, Hall, Howard, Wheeler, and Valley).

Additionally, we discovered an unpublished specimen of $P$. f. perniger from eastern Nebraska at the UNSM. In May 1983, a female was captured at Nine Mile Prairie in Lancaster County (UNSM 15418). We also obtained reference to a capture in a restored tallgrass prairie in Douglas County (Vacanti 1981, Vacanti and Geluso 1985). Around 1 September 1979, a female was captured in a region of the restored prairie that had burned 3.5 months earlier (Vacanti 1981).

\section{Habitat}

The plains pocket mouse was captured consistently on friable, sandy soils in grazed and ungrazed pastures as well as in roadside right-ofways along paved highways, gravel roads, and unmaintained 2-track jeep trails. In highly disturbed areas, such as roadside right-of-ways, $P$. flavescens frequently was captured in areas with an abundance of ragweed (Ambrosia), cheatgrass (Bromus tectorum), and plantain (Plantago). In less disturbed areas, common forbs and shrubs included leadplant (Amorpha canescens), evening primrose (Oenothera), ground cherry (Physalis), sunflower (Helianthus), and sagebrush (Artemisia), whereas common grasses included brome (Bromus), needle and thread (Hesperostipa comata), bluestem (Andropogon), and little bluestem (Schizachyrium scoparium). Height of vegetation near capture sites typically was $<30 \mathrm{~cm}$, and many areas with P. flavescens resembled habitats in the Sandhill Region of central Nebraska.

At capture sites with $P$. flavescens, mean total vegetative cover was $59 \%$ (range 10\%-100\%, $\mathrm{SE}=2.7, n=70$ ) and bare ground was $41 \%$ (range 0\%-90\%, SE $=2.7, n=70$ ). Additionally at capture sites, mean percentage of cover by grasses was $36 \%$ (range $0 \%-90 \%, \mathrm{SE}=2.8$, $n=70$ ), cover by forbs was $23 \%$ (range $0 \%-75 \%, \mathrm{SE}=2.0, n=70$ ), and cover by shrubs was $<1 \%$ (range $0 \%-15 \%, \mathrm{SE}=0.21$, $n=70)$.

\section{Reproduction}

We documented lactating female $P$. flavescens on $4,9,13,14$, and 23 July. Pregnant individuals were captured on $5,7,9,11,14,26$ July, and 1 August. Number of embryos ranged from 4 to 7 , with a mean of 4.9 and mode of 4 $(n=8$ pregnant females). Individuals designated 

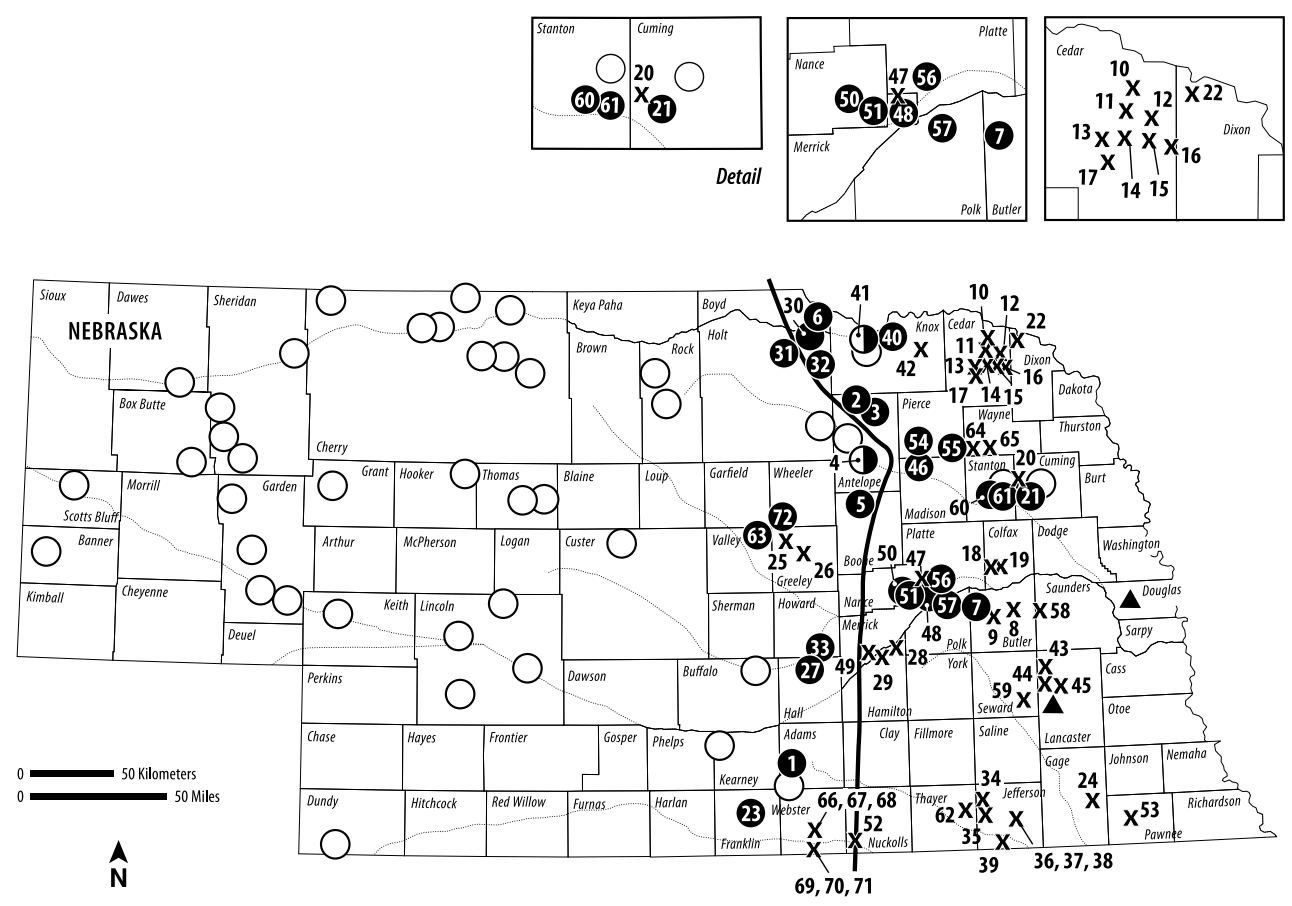

Fig. 1. Localities of occurrence for the plains pocket mouse (Perognathus flavescens) in Nebraska. The dark line depicts the subspecific boundary for the western subspecies (P. f. flavescens) and eastern subspecies (P. f. perniger). Open circles represent records published in Jones (1964). Half-closed circles represent localities where we documented the species at formerly published locations in Jones (1964). Closed circles represent new localities based on this study. Triangles represent additional observations by others obtained in eastern Nebraska after Jones (1964) and before our study (see text). X's represent localities without captures during our survey in 2008. For numbers associated with symbols, see Appendix 1 and 2 for details of localities.

as juveniles, based on a grayish appearance of pelage, were observed $4,5,7,8,11,12,13,14$, 26 July and 1 August. Testicular lengths of males kept as vouchers from 4 July to 2 August ranged from 4 to $10 \mathrm{~mm}(\bar{x}=6.6, \mathrm{SE}$ $=0.3$, mode $=6, n=22$ ).

\section{Coloration}

Our darkest individuals with respect to coloration of guard hairs on the dorsum were captured south of the Platte River in Butler and Polk counties (UNSM 29378, 29408). Other individuals with darker dorsal coloration were captured in northern Antelope, northern Holt, Knox, and Pierce counties. Our specimens from Boyd, Cuming, Madison, Nance, Merrick, Platte, and Stanton counties were not as dark as our other specimens but still were darker with respect to dorsal coloration than P. $f$. flavescens from the Sandhill Region of western and central Nebraska. The specimen from Lancaster County also had a dark dorsal coloration.
We recorded venter coloration for 60 individuals in eastern Nebraska- $53 \%$ were white, $43 \%$ were ochraceous, and 3\% had a slight ochraceous wash. Individuals with ochaceous venters were observed in 9 counties (Antelope, Butler, Holt, Knox, Madison, Nance, Pierce, Polk, and Wheeler). All captures from Stanton and Cuming counties had white venters $(n=$ 16). The individual from Lancaster County had an ochraceous venter.

\section{Discussion}

\section{Current Status and Distribution}

The plains pocket mouse, $P$. $f$. perniger, is firmly established in parts of northeastern and east-central Nebraska (Fig. 1). We readily documented individuals at most localities with sandy, friable soils with moderately sparse vegetation where we suspected the species to occur prior to deployment of traps. Moreover, trapping efforts at such sites were minimal, and 
we usually captured plains pocket mice on the first night with $\leq 80$ traps. The paucity of prior records in eastern Nebraska (Jones 1964, Benedict et al. 2000) likely reflected a lack of trapping in appropriate habitats in northeastern and east-central parts of the state in recent decades, as well as the past. Documentation of individuals near former sites in northeastern Nebraska as reported by Jones (1964) shows that populations have persisted at or near former capture sites with suitable habitats. Captures in east-central Nebraska (Butler, Merrick, Nance, Platte, and Polk counties) demonstrate that these previously unknown populations existed in the state. In addition, captures of $P . f$. flavescens along its eastern boundary and in south-central Nebraska further our understanding of its habitat associations, distribution, and natural history in the state.

Examination of soil types and distribution of $P$. $f$. perniger in eastern Nebraska supports statements regarding the association between sandy soils and occurrence of the plains pocket mouse (Jones et al. 1983, see Monk and Jones 1996). Distribution of $P$. f. perniger in northeastern Nebraska abruptly ends upon contact with the Nora-Moody-Judson soils described in part as fine-silty (SNR 2012). In southeastern Nebraska, the species' distribution appears limited by the Hastings-Crete-Fillmore soils also described as silty (SNR 2012). All of our captures corresponded with sandy soils, many of which consisted of long fingers of stratum that protruded into areas associated with alluvium along the Platte, Loup, and Elkhorn rivers. If silty and clay soils limit the occurrence of $P$. flavescens, then many clusters of localities of occurrence in eastern Nebraska (Fig. 1) represent disjunct, isolated populations.

In eastern Nebraska, $P$. $f$. perniger does not appear to inhabit a broad geographic area but currently occurs as local, disjunct populations mainly in east-central and northeastern parts of the state. The former distribution of $P$. flavescens in Nebraska is unknown prior to cultivation. Jones (1964) stated that P. f. perniger may have occurred in southeastern Nebraska, albeit not a single individual was reported from the region. We also did not secure or uncover any records from the region. Although Jones (1964) and Benedict et al. (2000) suggested that the plains pocket mouse may be absent from former parts of its historic range in southeastern Nebraska, that hypothesis cannot be tested in absence of historical data. Alternatively, $P . f$. perniger might have never occurred in southeastern Nebraska, or its occurrence in the region only is sporadic or accidental. Records of captures from Douglas and Lancaster counties in extreme east-central Nebraska might represent such incidental captures. From our understanding of the species, it is unclear how those 2 sites could contain sustainable populations in areas with compact soils and dense vegetation. We predict that the past distribution of $P$. $f$. perniger was limited and discontinuous based on unsuitable soils throughout much of eastern Nebraska. If our prediction is accurate, this species may not have been so negatively impacted by past widespread agricultural practices in eastern Nebraska because of the species' propensity to reside in areas dominated by sandy soils used mainly for cattle grazing. In the eastern Great Plains, P. flavescens likely was never abundant in eastern parts of its distribution where silty or clay soils dominate the landscape, although its distribution coincides with the distribution of tallgrass prairies.

We documented $P$. f. flavescens, the western subspecies in Nebraska, across much of its entire eastern distribution, an area generally lacking prior records (Fig. 1; Jones 1964). Other areas in central parts of the state also may support the species, but only those areas that do not consist of clay or silty soils. Populations in southern Antelope, Boone, Valley, and Wheeler counties represent the easternmost extent of contiguous sandy soils associated with the Sandhill Region of the state (Bleed and Flowerday 1989). Examination of records in southcentral Nebraska further suggest that $P$. f. flavescens may not occur over much of the area where the Coly-Uly-Holdrege soils persist, such as in Frontier, Gosper, Phelps, Furnas, Harlan, and parts of Custer, Dawson, Buffalo, and Sherman counties (SNR 2012). Our only exception where an individual was captured on silty soils, according to the soils map (SNR 2012), was in north-central Franklin County; however, the immediate area where the individual was captured consisted of friable, sandy soil. Likewise, populations in Adams, Hall, Howard, and Kearney counties appear associated with other isolated areas of sandy soils.

\section{Taxonomic Status Based on Colorations}

Osgood (1904) originally described P. f. perniger, in part, based on a darker-colored dorsum. 
Jones (1964) relied on this characteristic, in part, in discriminating between subspecies in Nebraska. We based our subspecific determination of specimens solely on dorsal coloration because of the lack of utility in venter coloration, brightness of lateral line, and cranial size. By visiting museums, we observed many of the specimens of $P . f$. perniger and $P . f$. flavescens known in collections. One of the clearest separations in dorsal colorations between 2 nearby subspecific populations was observed in Antelope County, Nebraska. Here, specimens near Neligh were lighter colored, whereas specimens from multiple locations about $30 \mathrm{~km}$ to the north near Orchard and Royal had darker dorsal colorations. Areas by Neligh represent the easternmost contiguous areas of the Sandhills (Bleed and Flowerday 1989). Although specimens from northern Antelope County and other nearby populations of $P$. f. perniger in northeastern Nebraska were darker in coloration, our 2 specimens from south of the Platte River had the darkest dorsal coloration (Butler and Polk counties) of our specimens. Interestingly, the darkest of all $P$. $f$. perniger we observed were from Lancaster County, Nebraska (UNSM 15418) and Iowa (UNSM 1, 29999, 30000, 30001), likely reflecting local edaphic conditions. Thus, within $P$. $f$. perniger there appears to be variation in this trait, with the darkest colorations in southernmost specimens and generally lighter colorations in individuals to the north in South Dakota, Minnesota, and northeastern Nebraska. Jones (1964) also noted intergradation of $P . f$. flavescens and P. f. perniger in Nebraska. We noted that some areas had a mixture of lighter and darker individuals, with some individuals possibly considered intergrades. Areas with some inconsistencies in coloration included Potter County in South Dakota and Hall, Holt, Keya Paha, Stanton, Valley, and Wheeler counties in Nebraska.

Osgood (1904) also described P. f. perniger, in part, based on encroachment of ochraceous coloration on the underside of individuals, but inconsistency in this trait among Nebraskan specimens rendered it of little taxonomic use (Jones 1964). Jones (1964) further commented that specimens from Knox County showed this trait, as well as a few specimens from central Nebraska. Our specimens also demonstrate the variability and lack of utility for this characteristic, and individuals with such coloration are more widespread in eastern Nebraska than originally reported. Reed and Choate (1986) observed that more northern populations appeared to have such a trait. Many of our $P$. $f$. perniger had ochraceous venters, with the major exception being those individuals from Stanton and Cuming counties, which all had white venters, lending support to the isolated nature of many of these populations in the region.

Jones (1964) also used paleness and brightness of the lateral line to assist in distinguishing subspecies, with $P$. f. perniger having the brightest and richest coloration, and P. f. flavescens having a pale lateral line. We observed inconsistencies among specimens. Of note, specimens from the southern parts of its distribution (Lancaster County, Nebraska, and Iowa specimens at UNSM) had the brightest lateral lines (this same coloration also was present on the venter), whereas individuals in South Dakota, Minnesota, and northeastern Nebraska usually did not have bright lateral lines. As with venter coloration, aspects of lateral line were not useful in distinguishing between subspecies in Nebraska, especially among northern populations of P.f. perniger and P. f. flavescens.

\section{Conservation and Management}

During our survey, we documented the plains pocket mouse in areas without former records and parts of eastern Nebraska where individuals have not been documented in decades. Isolated areas of sandy soils with sparse vegetation appear to be important strongholds for P. flavescens along much of its easternmost distributional limits in the state. Because of the general reliance of $P$. flavescens on such a specific habitat (see Monk and Jones 1996) and isolation of many of these areas, conservation and maintenance of sandy habitats appear warranted for the long-term existence of $P$. flavescens in eastern Nebraska. Continued threats to habitats include the conversion of prairies and pasture lands to agricultural croplands, especially in years when corn prices are high, and a lack of disturbance regimes to reset succession in these systems. Grazing by domestic livestock on lands with sandy soils helps maintain areas of sparse vegetation likely requisite for pocket mice and other sandadapted species in eastern Nebraska. Ballinger and Jones (1985) demonstrated the importance of grazing in maintaining open, sandy habitats for 2 species of lizards in the Sandhills of 
Nebraska. Discontinuation of grazing was associated with a decrease in blowouts and sparse vegetation, as well as a concomitant decrease in prairie lizards (Sceloporus consobrinus, formally referred to as $S$. undulatus) and lesser earless lizards (Holbrookia maculata). Similarly at the Sunny Hollow Wildlife Management Area in Nance County, we captured $P$. flavescens only along the edge of the property, adjacent to private lands that contained large areas of exposed sand and pastures grazed by cattle. In contrast, we did not detect $P$. flavescens in the interior of this property where vegetation was dense and lacked disturbance by cattle. In the Sandhills of the state, one of us has captured many plains pocket mice in open sandy habitats, but areas with dense vegetation, albeit a sandy substrate, lacked pocket mice (K. Geluso, unpublished data). Thus, areas suitable for plains pocket mice in eastern $\mathrm{Ne}$ braska also likely need a mechanism of disturbance to maintain open, sandy habitats.

\section{ACKNOWLEDGMENTS}

This study was funded by the Nebraska Game and Parks Commission to survey for the plains pocket mouse and plains harvest mouse in eastern Nebraska. We thank Mike Fritz (Nebraska Game and Parks Commission) for his assistance with grant-related matters; Angie Fox (UNSM) for preparing Fig. 1; Trish Freeman and Tom Labedz (UNSM), Curtis Schmidt (FHSM), and Robert Timm (KU) for assistance with museum matters associated with this project; and Sheila Bartels, Tony Bernbeck, Edward Higel, Bob Kapke, Dick Kujath, and Mrs. Wulf for providing access to their land.

\section{Literature Cited}

Ballinger, R.E., AND S.M. Jones. 1985. Ecological disturbance in a Sandhills prairie: impact and importance to the lizard community on Arapaho Prairie in western Nebraska. Prairie Naturalist 17:91-100.

Benedict, R.A., P.W. Freeman, and H.H. Genoways. 1996. Prairie legacies-mammals. Pages 149-166 in F.B. Samson and F.L. Knopf, editors, Prairie conservation: preserving North America's most endangered ecosystem. Island Press, Washington, DC.

Benedict, R.A., H.H. Genoways, and P.W. Freeman. 2000. Shifting distributional patterns of mammals in Nebraska. Transactions of the Nebraska Academy of Sciences 26:55-84.

Birney, E.C. 1999. Status of the plains pocket mouse (Perognathus flavescens) at the Twin Cities Army Ammunition Plant. Final Report. Minnesota Department of Natural Resources, St. Paul, MN.
Bleed, A., AND C. Flowerday. 1989. An atlas of the Sand Hills. Conservation and Survey Division, University of Nebraska-Lincoln, Resource Atlas No. 5.

DeLorme Mapping Company. 2000. Nebraska atlas and gazetteer. 2nd edition. DeLorme Publishing Company, Yarmouth, ME.

Easterla, D.A. 1967. First specimens of plains pocket mouse from Missouri. Journal of Mammalogy 48: 479-480.

Fleharty, E.D., and R. Channell. 1997. Historical implications and characteristics of assemblages of small mammals in west-central Kansas. Pages 155-178 in T.L. Yates, W.L. Gannon, and D.E. Wilson, editors, Life among the muses: papers in honor of James S. Findley. Special Publication No. 3, Museum of Southwestern Biology, Albuquerque, NM.

Hall, E.R. 1981. The mammals of North America. 2nd edition. John Wiley \& Sons, New York, NY.

Jones, J.K., JR. 1964. Distribution and taxonomy of mammals of Nebraska. Publication of the Museum of Natural History, University of Kansas 16:1-356.

Jones, J.K., Jr., D.M. Armstrong, R.S. Hoffmann, And C. Jones. 1983. Mammals of the Northern Great Plains. University of Nebraska Press, Lincoln, NE.

Monk, R.R., And J.K. Jones JR. 1996. Perognathus flavescens. Mammalian Species 525:1-4.

Osgood, W.H. 1904. Two new pocket mice of the genus Perognathus. Proceedings of the Biological Society of Washington 17:127-128.

Otto, H.W., And J.A. White. 2011. Late seasonal captures of the plains pocket mouse (Perognathus flavescens) in Iowa. Prairie Naturalist 43:124-126.

REED, K.M., AND J.R. CHOATE. 1986. Geographic variation in the plains pocket mouse (Perognathus flavescens) on the Great Plains. Texas Journal of Science 38: $227-240$.

Samson, F., And F. KnOPF. 1994. Prairie conservation in North America. BioScience 44:418-421.

Schneider, R., M. Humpert, K. Stoner, and G. SteinAUER. 2005. The Nebraska Natural Legacy Project: a comprehensive wildlife conservation strategy. Nebraska Game and Parks Commission, Lincoln, NE.

Schwartz, C.W., AND E.R. Schwartz. 2001. The wild mammals of Missouri. 2nd revised edition. University of Missouri Press, Columbia, MO.

[SNR] School of Natural Resources, University of Nebraska-Lincoln. 2012. General soils map of Nebraska. [Last accessed 17 April 2012]. Available from: http://snr.unl.edu/data/geologysoils/soilmap/ NebraskaSoilMap.asp

VACANTI, P.L. 1981. Effects of controlled burning on small mammal populations of a restored tallgrass prairie. Master's thesis, University of Nebraska at Omaha, NE.

VACANTI, P.L., AND K.N. GELUSO. 1985. Recolonization of a burned prairie by meadow voles (Microtus pennsylvanicus). Prairie Naturalist 17:15-22.

Williams, D.F., H.H. Genoways, and J.K. Braun. 1993. Taxonomy. Pages 38-196 in H.H. Genoways and J.H. Brown, editors, Biology of the Heteromyidae. American Society of Mammalogists, Special Publication 10.

Wilson, G.M., J.B. Bowles, and J.W. Van ZeE. 1996. Current status of the plains pocket mouse, Perognathus flavescens, in Iowa. Journal of the Iowa Academy of Science 103:52-55.

Received 27 April 2012 Accepted 21 August 2012 
APPENDIX 1. Localities of occurrence for the plains pocket mouse (Perognathus flavescens) in eastern Nebraska during our field efforts in 2008. Listed below are dates of capture, number of trap-nights, number of each sex captured, and specimen numbers for animals retained as vouchers. All voucher specimens were deposited in the zoological collection at the University of Nebraska State Museum (UNSM), and corresponding UNSM ZM numbers are given in brackets. Numbers preceding localities correspond to those in Fig. 1.

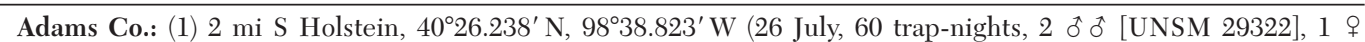
[UNSM 29323]). Antelope Co.: (2) $5.2 \mathrm{mi} \mathrm{N}$ Roval, $42^{\circ} 24.652^{\prime} \mathrm{N}, 98^{\circ} 02.247^{\prime} \mathrm{W}$ (11 July, 60 trap-nights, 1 ㅇ [UNSM 29387]); (3) $3 \mathrm{mi} \mathrm{N}, 1.9 \mathrm{mi}$ E Royal, 42²2.722' N, 98 $05.310^{\prime} \mathrm{W}$ (11 July, 40 trap-nights, 1 oे [UNSM 29388]); (4) $2.1 \mathrm{mi} \mathrm{S}$ Neligh, E side Hwy. 14, 42 $06.024^{\prime} \mathrm{N}, 98^{\circ} 02.812^{\prime} \mathrm{W}$ (10 and 11 July, 220 total trap-nights, 3 ơ ơ [UNSM 29385], 1 \%). Boone Co.: (5) Olson Nature Preserve, $2.8 \mathrm{mi} \mathrm{S,} 2.1 \mathrm{mi}$ W Petersburg, $41^{\circ} 47.840^{\prime} \mathrm{N}, 98^{\circ} 06.571^{\prime} \mathrm{W}$ (25 July, 40 trap-

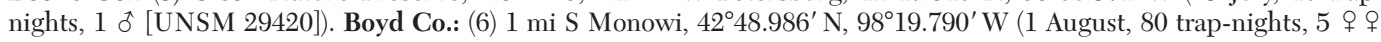
[UNSM 29330]). Butler Co.: (7) $7 \mathrm{mi} \mathrm{S}, 0.7 \mathrm{mi}$ E Columbus, 41 ${ }^{\circ} 20.212^{\prime} \mathrm{N}, 97^{\circ} 21.542^{\prime} \mathrm{W}$ (17 July, 40 trap-nights, 1 o [UNSM 29408]). Cuming Co.: (21) $2 \mathrm{mi} \mathrm{S,} 3 \mathrm{mi}$ W Wisner, 41 $57.623^{\prime} \mathrm{N}, 96^{\circ} 58.307^{\prime} \mathrm{W}$ (14 July, 115 trap-nights, 1 ठ [UNSM 29399], 1 q [UNSM 29398]). Franklin Co.: (23) $0.5 \mathrm{mi}$ E Hwy. 10 on Hwy. 4, $2.1 \mathrm{mi} \mathrm{W,} 1.8$ mi S Upland,

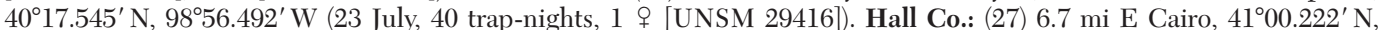
$98^{\circ} 28.810^{\prime} \mathrm{W}$ (25 July, 30 trap-nights, 1 ơ [UNSM 29422]). Holt Co.: (30) Redbird State Wildlife Management Area, $42^{\circ} 45.372^{\prime} \mathrm{N}, 98^{\circ} 26.096^{\prime} \mathrm{W}$ (5 and 6 July, 160 total trap-nights, 2 ơ oे [UNSM 29362], 2 우 우 [UNSM 29363]); (31) $18.7 \mathrm{mi} \mathrm{N}$ $11.3 \mathrm{mi}$ E O’Neill, $42^{\circ} 44.188^{\prime} \mathrm{N}, 98^{\circ} 26.543^{\prime} \mathrm{W}$ (6 July, 40 trap-nights, 1 ô [UNSM 29365]); (32) 15 mi N, $5.5 \mathrm{mi} \mathrm{E}$

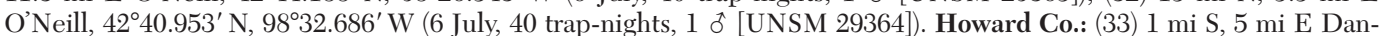
nebrog, $41^{\circ} 06.338^{\prime}$ N, $98^{\circ} 26.845^{\prime}$ W (25 July, 36 trap-nights, 1 q [UNSM 29418]). Knox Co.: (40) Hwy. 14, 1.4 mi S Hwy. $12,42^{\circ} 43.838^{\prime} \mathrm{N}, 98^{\circ} 02.919^{\prime} \mathrm{W}\left(4\right.$ and 5 July, 240 total trap-nights, 2 oิ $^{\dagger}$ [UNSM 29360], 3 9 o [UNSM 29359]) and (41) 3 mi S, 4 mi E Niobrara, $42^{\circ} 42.624^{\prime}$ N, $97^{\circ} 57.279^{\prime}$ W (31 July, 80 trap-nights, 1 o [UNSM 29329]). Madison Co.: (46) 3 mi N, 1.8 mi W Meadow Grove (9 July, 80 trap-nights, 1 ㅇ [UNSM 29379]). Merrick Co.: (48) 3 mi N, 2.5 mi E Silver Creek, $41^{\circ} 21.535^{\prime} \mathrm{N}, 97^{\circ} 37.050^{\prime} \mathrm{W}$ (8 July, 40 trap-nights, $1 \delta^{\dagger}$ [UNSM 29375]). Nance Co.: (50) Sunny Hollow State Wildlife Management Area, $41^{\circ} 22.830^{\prime} \mathrm{N}, 97^{\circ} 44.321^{\prime} \mathrm{W}$ (7 July, 80 trap-nights, 1 o [UNSM 29373], 1 $\uparrow$ ) and (51) Sunny

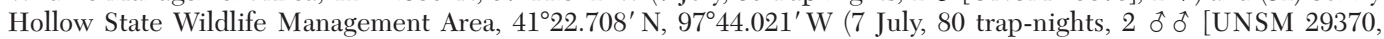

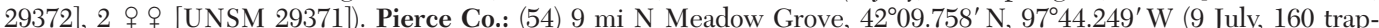
nights, 2 후 ot [UNSM 29382], 5 우 ㅇNSM 29380, 29381, 29383]) and (55) $0.1 \mathrm{mi} \mathrm{S}, 3 \mathrm{mi} \mathrm{E}$ Hadar, $42^{\circ} 06.193^{\prime} \mathrm{N}$, $97^{\circ} 23.255^{\prime} \mathrm{W}$ (12 July, 75 trap-nights, 1 ô [UNSM 29389]). Platte Co.: (56) $6.5 \mathrm{mi} \mathrm{N}, 3.5 \mathrm{mi} \mathrm{E}$ Silver Creek, $41^{\circ} 24.674^{\prime} \mathrm{N}, 97^{\circ} 35.958^{\prime} \mathrm{W}$ (6 and 7 July, 40 trap-nights, 1 o [UNSM 29366], 2 o + [ [UNSM 29369]). Polk Co.: (57) 5 mi S, $0.5 \mathrm{mi}$ W Duncan, $41^{\circ} 18.767^{\prime} \mathrm{N}, 97^{\circ} 30.163^{\prime} \mathrm{W}$ (8 July, 80 trap-nights, 1 ơ [UNSM 29378]). Stanton Co.: (60) 1 mi S, 3 mi E Stanton, $41^{\circ} 55.928^{\prime} \mathrm{N}, 97^{\circ} 09.358^{\prime} \mathrm{W}$ (12 July, 100 trap-nights, 1 우 [UNSM 29391]) and (61) 2 mi S, 3 mi E Stanton, $41^{\circ} 55.674^{\prime} \mathrm{N}, 97^{\circ} 09.966^{\prime} \mathrm{W}$ (13 and 14 July, 330 total trap-nights, 7 o 0 o [UNSM 29393], 7 ㅇ ㅇ [UNSM 29394]). Valley Co.: (63) $10 \mathrm{mi} \mathrm{N}, 5 \mathrm{mi} \mathrm{E}$ Ord, $41^{\circ} 44.426^{\prime} \mathrm{N}, 98^{\circ} 49.121^{\prime} \mathrm{W}$ (2 August, 40 trap-nights, 1 ơ [UNSM 29331]). Wheeler Co.: (72) $3 \mathrm{mi} \mathrm{S}, 1 \mathrm{mi}$ E Ericson, $41^{\circ} 44.598^{\prime} \mathrm{N}, 98^{\circ} 39.756^{\prime} \mathrm{W}$ (2 August, 20 trap-nights, 1 ôे [UNSM 29332]).

Appendix 2 on page 562 
APPENDIX 2. Localities where we did not capture a plains pocket mouse (Perognathus flavescens) in eastern Nebraska in 2008. Dates of survey and trap-nights are given in parentheses. Numbers preceding localities correspond to locations in Fig. 1.

Butler Co.: (8) $0.8 \mathrm{mi} \mathrm{S}$ Octavia, $41^{\circ} 20.171^{\prime} \mathrm{N}, 97^{\circ} 03.728^{\prime} \mathrm{W}$ (30 July, 40 trap-nights) and (9) $2.6 \mathrm{mi} \mathrm{S}$ Bellwood, $41^{\circ} 17.969^{\prime} \mathrm{N}, 97^{\circ} 14.074^{\prime} \mathrm{W}$ (17 and 30 July, 120 total trap-nights). Cedar Co.: (10) 6.3 mi N, 3.8 mi E Hartington, $42^{\circ} 42.601^{\prime} \mathrm{N}, 97^{\circ} 11.659^{\prime} \mathrm{W}$ (15 July, 30 trap-nights); (11) $2.5 \mathrm{mi} \mathrm{N}, 7.7 \mathrm{mi}$ E Hartington, $42^{\circ} 39.346^{\prime} \mathrm{N}, 97^{\circ} 06.989^{\prime} \mathrm{W}(15$ July, 40 trap-nights); (12) $1.5 \mathrm{mi} \mathrm{N}, 8.9 \mathrm{mi}$ E Hartington, $42^{\circ} 38.478^{\prime} \mathrm{N}, 97^{\circ} 05.631^{\prime} \mathrm{W}$ (15 July, 50 trap-nights); (13) $0.5 \mathrm{mi} \mathrm{S}$ $3.5 \mathrm{mi}$ E Hartington, $42^{\circ} 36.735^{\prime} \mathrm{N}, 97^{\circ} 12.115^{\prime} \mathrm{W}$ (16 July, 40 trap-nights); (14) 0.5 mi S, 5.5 mi E Hartington, $42^{\circ} 36.739^{\prime} \mathrm{N}, 97^{\circ} 09.848^{\prime} \mathrm{W}$ (16 July, 20 trap-nights); (15) $3.6 \mathrm{mi}$ W Hartington, $42^{\circ} 36.764^{\prime} \mathrm{N}, 97^{\circ} 20.384^{\prime} \mathrm{W}$ (15 July, 40 trap-nights); (16) $0.6 \mathrm{mi} \mathrm{S}, 9 \mathrm{mi}$ E Hartington, 42 $36.563^{\prime} \mathrm{N}, 97^{\circ} 05.651^{\prime} \mathrm{W}$ (16 July, 20 trap-nights); and (17) $1.6 \mathrm{mi} \mathrm{S,} 2 \mathrm{mi} \mathrm{W}$ Hartington, $42^{\circ} 35.280^{\prime} \mathrm{N}, 97^{\circ} 18.529^{\prime} \mathrm{W}$ (15 and 16 July, 80 trap-nights). Colfax Co.: (18) $4 \mathrm{mi} \mathrm{N}, 3 \mathrm{mi} \mathrm{W}$ Schuyler, $41^{\circ} 30.701^{\prime} \mathrm{N}, 97^{\circ} 07.052^{\prime} \mathrm{W}$ (29 July, 40 trap-nights) and (19) $4 \mathrm{mi} \mathrm{N}, 2.6 \mathrm{mi} \mathrm{W}$ Schuyler, 41 $30.635^{\prime} \mathrm{N}, 97^{\circ} 06.592^{\prime} \mathrm{W}(2.9$ July, 40 trap-nights). Cuming Co.: (20) $0.5 \mathrm{mi} \mathrm{S}, 4.8 \mathrm{mi} \mathrm{W}$ Wisner, $41^{\circ} 58.941^{\prime} \mathrm{N}, 9^{\circ} 00.063^{\prime} \mathrm{W}$ (14 July, 5 trap-nights).

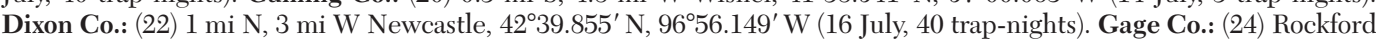
Lake SRA, $1.75 \mathrm{mi} \mathrm{S}, 1 \mathrm{mi}$ E Rockford, 40 $13.591^{\prime} \mathrm{N}, 96^{\circ} 34.732^{\prime} \mathrm{W}$ (10 June, 160 trap-nights). Greeley Co.: (25) $4.6 \mathrm{mi}$ S, $1 \mathrm{mi}$ E Ericson, $41^{\circ} 44.139^{\prime} \mathrm{N}, 98^{\circ} 39.780^{\prime} \mathrm{W}$ (2 August, 10 trap-nights) and (26) $1.4 \mathrm{mi} \mathrm{S}$ Hwy. 91 on Hwy. 281, $41^{\circ} 40.521^{\prime} \mathrm{N}, 98^{\circ} 32.395^{\prime} \mathrm{W}$ (2.5 July, 40 trap-nights). Hamilton Co.: (28) $3.2 \mathrm{mi} \mathrm{E}$ Hwy. 14 on Hwy. 66, 41 $04.501^{\prime} \mathrm{N}$, $97^{\circ} 56.360^{\prime} \mathrm{W}$ (17 July, 20 trap-nights) and (29) $0.7 \mathrm{mi} \mathrm{N}, 3.5 \mathrm{mi} \mathrm{W}$ Marquette, $41^{\circ} 00.891^{\prime} \mathrm{N}, 98^{\circ} 04.440^{\prime} \mathrm{W}(10 \mathrm{July}$ and 17 July, 105 trap-nights). Jefferson Co.: (34) 2 mi E Alexandria, $40^{\circ} 14.800^{\prime} \mathrm{N}, 97^{\circ} 21.472^{\prime} \mathrm{W}(18,19$, and 20 June, 240 total trap-nights); (35) Alexandria State Wildlife Management Area, $0.5 \mathrm{mi} \mathrm{S}, 3 \mathrm{mi}$ E Alexandria, $40^{\circ} 14.642^{\prime} \mathrm{N}$, $97^{\circ} 19.970^{\prime} \mathrm{W}$ (18, 19, and 20 June, 240 total trap-nights); (36) Rock Creek Station State Recreation Area, 3 mi N, 2 mi E Endicott, $40^{\circ} 06.903^{\prime} \mathrm{N}, 97^{\circ} 03.971^{\prime} \mathrm{W}(11,12$, and 13 June, 120 total trap-nights); (37) Rock Creek Station State Recreation Area, $2.5 \mathrm{mi} \mathrm{N}, 2 \mathrm{mi} \mathrm{E}$ Endicott, $40^{\circ} 06.223^{\prime} \mathrm{N}, 9^{\circ} 02.969^{\prime} \mathrm{W}$ (11, 12, and 13 June, 240 total trap-nights); (38) 1 mi S, 5 mi E Fairbury, $40^{\circ} 08.175^{\prime} \mathrm{N}, 97^{\circ} 04.027^{\prime} \mathrm{W}(11,12$, and 13 June, 120 total trap-nights); (39) 8 mi S, $1.3 \mathrm{mi}$ W Fairbury, $40^{\circ} 01.909^{\prime} \mathrm{N}, 97^{\circ} 11.411^{\prime} \mathrm{W}(24,25$, and 26 June, 480 total trap-nights). Knox Co.: (42) 6 mi N, 0.7 mi W Bloomfield, $42^{\circ} 41.073^{\prime} \mathrm{N}, 97^{\circ} 40.677^{\prime} \mathrm{W}$ (16 July, 60 trap-nights). Lancaster Co.: (43) Branched Oak State Recreation Area, 4 mi N Malcom, 40 $59.379^{\prime} \mathrm{N}, 96^{\circ} 52.243^{\prime} \mathrm{W}$ (27, 28, and 29 June, 240 total trap-nights); (44) Branched Oak State Recreation Area, 4 mi N Malcom, 40 $58.738^{\prime}$ N, $96^{\circ} 50.936^{\prime} \mathrm{W}$ (27, 28, and 29 June, 240 total trap-nights); (45) Little Salt Creek State Wildlife Management Area, 3.5 mi E Raymond, 4057.492' N, 96 $42.368^{\prime}$ W (30 June, 1 July, and 2 July, 480 total trap-nights). Merrick Co.: (47) 4 mi N, 2.5 mi E Silver Creek, 41 $21.324^{\prime}$ N, $97^{\circ} 37.056^{\prime}$ W (8 July, 80 trap-nights) and (49) Bader Memorial Park (11 July, 40 trap-nights). Nuckolls Co.: (52) $5 \mathrm{mi} \mathrm{N}, 8.4 \mathrm{mi}$ W Superior, $40^{\circ} 05.375^{\prime} \mathrm{N}$, $98^{\circ} 13.681^{\prime} \mathrm{W}$ (25 July, 120 trap-nights). Pawnee Co.: (53) Burchard Lake, 40 $10.076^{\prime} \mathrm{N}, 96^{\circ} 18.213^{\prime} \mathrm{W}$ (7, 8, and 9 June, 480 total trap-nights). Saunders Co.: (58) 2 mi E Abie, $41^{\circ} 20.155^{\prime}$ N, $96^{\circ} 54.484^{\prime} \mathrm{W}$ (30 July, 20 trap-nights). Seward Co.: (59) $1.5 \mathrm{mi} \mathrm{N}, 1 \mathrm{mi} \mathrm{W}$ Pleasant Dale, $40^{\circ} 48.839^{\prime} \mathrm{N}, 96^{\circ} 56.931^{\prime} \mathrm{W}$ (27 and 28 July, 320 total trap-nights). Thayer Co.: (62) $2 \mathrm{mi} \mathrm{S}, 1 \mathrm{mi} \mathrm{W}$ Alexandria, $40^{\circ} 13.008^{\prime} \mathrm{N}, 97^{\circ} 24.326^{\prime} \mathrm{W}(21,22$, and 23 June, 480 total trap-nights). Wayne Co.: (64) 0.2 mi S Hwy. 35 on Ave. $561,42^{\circ} 06.130^{\prime} \mathrm{N}, 97^{\circ} 18.603^{\prime} \mathrm{W}$ (11 July, 25 trap-nights) and (65) 4.8 mi E, 0.5 mi S Hoskins (13 July, 120 trap-nights). Webster Co.: (66) $4.2 \mathrm{mi} \mathrm{N}$ Red Cloud, 4008.725' N, 98 $31.139^{\prime} \mathrm{W}$ (22 July, 30 trap-nights); (67) $3.8 \mathrm{mi} \mathrm{N}$ Red Cloud, $40^{\circ} 08.461^{\prime} \mathrm{N}, 98^{\circ} 31.135^{\prime} \mathrm{W}$ (22 July, 10 trap-nights); (68) $3.7 \mathrm{mi} \mathrm{N}$ Red Cloud, 40 $08.321^{\prime} \mathrm{N}$, $98^{\circ} 31.135^{\prime} \mathrm{W}$ (23 July, 40 trap-nights); (69) $5 \mathrm{mi} \mathrm{S}$ Red Cloud, $40^{\circ} 01.021^{\prime} \mathrm{N}, 98^{\circ} 31.137^{\prime} \mathrm{W}$ (21, 22, and 23 July, 630 total trap-nights); (70) $5.5 \mathrm{mi} \mathrm{S}$ Red Cloud, $40^{\circ} 00.532^{\prime} \mathrm{N}, 98^{\circ} 31.137^{\prime} \mathrm{W}$ (21 and 22 July, 160 total trap-nights); (71) $5.9 \mathrm{mi} \mathrm{S}$ Red Cloud, $40^{\circ} 00.204^{\prime} \mathrm{N}, 98^{\circ} 31.369^{\prime} \mathrm{W}(21,22$, and 23 July, total 240 trap-nights). 